\title{
Exclusive maternal breastfeeding and the Breastfeeding Self-efficacy Scale
}

\author{
Aleitamento materno exclusivo e a Escala de Autoeficácia na Amamentação \\ Lactancia materna exclusiva y la Escala de Autoeficacia en el Amamantamiento
}

Edficher Margotti ${ }^{1}$, Matias Epifanio ${ }^{2}$

This study aimed at determining the factors related to the duration of exclusive breastfeeding and to associate them to the scores of the Breastfeeding Self-efficacy Scale. 300 mother-baby binomials were studied, from the capital cities of the southern region of Brazil in 2012, using the Breastfeeding Self-efficacy Scale during postpartum period and with intervals from 15 to 120 days after delivery. The average of the score of breastfeeding was 36 points. The risk factors for breastfeeding were: hospitals which were not Child Friendly ( $p=0.002$ ), schooling ( $\leq 8$ years of study; $p=0.004$ ), and working mother $(p=0.013)$. When evaluating the maternal breastfeeding after 120 days, the variables which were considered as protection factors for breastfeeding were the maternal age of majority $(p=0.039)$ and the score in the test of breastfeeding $(p=0.046)$. The variables for the exclusive breastfeeding were the maternal age of majority and the score in the test of breastfeeding.

Descriptors: Breast Feeding; Weaning; Self Efficacy; Risk Factors.

Objetivou-se determinar os fatores relacionados com o tempo de aleitamento materno exclusivo e associar aos escores da Escala de Autoeficácia na Amamentação. Estudou-se 300 binômios mãe-bebê, de duas capitais da Região Sul do Brasil em 2012, utilizando-se a Escala de Autoeficácia na Amamentação durante o puerpério e com intervalos de 15 até 120 dias após o parto. A média materna do escore de amamentação foi de 36 pontos. Os fatores de risco para a amamentação foram: hospitais não Amigos da Criança ( $p=0,002)$, escolaridade ( $\leq 8$ anos de estudo; $p=0,004)$ e mãe que trabalhava $(p=0,013)$. Ao avaliar o aleitamento materno aos 120 dias, as variáveis que se mostraram como fatores de proteção para a amamentação foram a maior idade materna $(p=0,039)$ e a pontuação no teste de amamentação $(p=0,046)$. Já aquelas para a amamentação exclusiva foram a maior idade materna e a pontuação no teste de amamentação.

Descritores: Aleitamento Materno; Desmame; Autoeficácia; Fatores de Risco.

El objetivo fue determinar los factores relacionados con el tiempo de lactancia materna exclusiva y asociar a las puntuaciones de la Escala de Autoeficacia en el amamantamiento. Se estudiaron 300 binomios madre-bebé de dos capitales del sur del Brasil en 2012, utilizándose la Escala de Autoeficacia en el amamantamiento durante el puerperio y en intervalos de 15 a 120 días después del parto. El promedio materno del escore de lactancia fue de 36 puntos. Los factores de riesgo para lactancia materna fueron: hospitales no Amigos del Niño ( $p=0,002)$, escolaridad ( $\leq 8$ años de estudio; $p=0,004)$ y madre que trabajaba $(p=0,013)$. Al evaluar la lactancia materna a los 120 días, mayor edad materna $(p=0,039)$ y puntuación en el examen de lactancia materna $(p=0,046)$ fueron las variables señaladas como factores de protección para el amamantamiento. Para lactancia materna exclusiva, fueron mayor edad de la madre y puntuación en el examen de amamantamiento.

Descriptores: Lactancia Materna; Destete; Autoeficacia; Factores de Riesgo.

\footnotetext{
${ }^{1}$ Universidade Federal do Amapá. Macapá, AP, Brazil.

${ }^{2}$ Pontifícia Universidade Católica do Rio Grande do Sul, Porto Alegre, RS, Brazil. 


\section{Introduction}

The practice of maternal breastfeeding is fundamental for the adequate growth and development of the child and for his physical and psychological health. No artificial eating formula is able to substitute the maternal milk in quality, specificity of nutrients and protection against diseases ${ }^{(1)}$.

The crescent recognition of the adequacy of the maternal milk to the nutritional needs of the newborns, and the occurrence of diseases, such as cardiovascular ones, diabetes mellitus type 2 , arterial hypertension, allergic diseases and the nutritional deviations, represented by overweight and by obesity, reinforce the indication of the World Health Organization to keep the maternal milk as exclusive nutritional source in the first 6 months of life ${ }^{(1)}$.

The World Health Organization professes that the child should be breastfed soon after birth, still in the delivery room. If this is not possible, the child must be breastfed in the first six hours of life. This initiative which was developed in the hospital enables the mother to have a greater incentive to exclusive maternal breastfeeding, more prevalence and prolonged length of breastfeeding.

Despite the benefits publicized on the importance of maternal breastfeeding, it is observed that a reduced number of mothers offer exclusive breastfeeding. Although in the first weeks the adhesion to maternal breastfeeding is high, the number of those who breastfeed is reduced before the baby is six months old ${ }^{(1)}$. Facing these findings, the maintenance of the maternal breastfeeding has been recognized as one of the fundamental components of the programs of promotion of health of the child.

The elaborations of programs which incentives the natural breastfeeding and their greater effectiveness depend on the knowledge and on the control of the more frequent risk factors for weaning in each population group or region. The maintenance of exclusive maternal breastfeeding occurs both in developed country as well as in countries under development.
Studies highlight a higher prevalence of exclusive maternal breastfeeding among mothers who are older than 20 years and with high-school/university education. Such mothers, pursuit what is best for their children, valuing the basic actions of promotion to health, such as the information concerning the benefits of breastfeeding ${ }^{(2-3)}$. On the other hand, primiparous mothers present a tendency to the risk of not offering exclusive maternal milk to the children, between the forth and the sixth months of life. So, the primiparous mother presented more susceptibility to the early weaning ${ }^{(4)}$.

The nursing mother at the time she starts working she has an enhanced risk to early offer different food rather than the maternal milk, especially cow's milk. The imminence of the return to the work environment leads the nursing mother to the decision of an early inclusion of artificial milk in the feeding habits of the child, directly jeopardizing the success of the exclusive maternal breastfeeding, and complementing and increasing the average time of the length of the mixed breastfeeding ${ }^{(4)}$.

Concerning the risk factors, there is evidence that the length of breastfeeding is associated to the kind of delivery. Children who are born through elective cesarean have the risk of weaning at the end of the first month of life ${ }^{(5)}$.

Due to the different aspects which involve the risk of non-exclusive breastfeeding up to six months of life, the assistance of the pregnant woman during the pre-natal is important. During this period there may occur interventions favoring the access of the mothers to the information concerning maternal breastfeeding, besides helping them understand all the aspects which involve breastfeeding, in order to avoid difficulties after the birth of the child, once the orientations strengthen the confidence and the maternal capacity to breastfeed ${ }^{(2-4)}$.

Maternal breastfeeding in the delivery room, soon after the birth or in less than six hours of post-partum, and the rooming (mother and child together in the maternity room) are protecting factors 
for the exclusive maternal breastfeeding, once the link and the interaction mother-baby is established still in the delivery, and the lactation is stimulated in the maternity, thus contributing to make maternal breastfeeding longer ${ }^{(6)}$.

A study evaluating newborns, in the southeastern region of Brazil, showed that $80 \%$ of exclusive maternal breastfeeding in babies up to 15 days of life, however, between 5 and 4 months, this rate was $21.2 \%{ }^{(7)} .51 .2 \%$ of those births occurred in accredited hospital such as Child Friendly Hospital Institutions, followed by those without the title (30\%) and under a process of titration (18.8\%). Such fact shows that being born in a Child Friendly Hospital widens the probability of the child to remain in exclusive maternal breastfeeding for a longer period of time ${ }^{(7)}$.

The objective of the Child Friendly Hospital Institution consists in mobilizing the health professionals and employees of hospital and maternities in order to provide changes in routines behaviors, aiming at preventing the early weaning. The set of measures to reach the targets was called 'Ten Steps for the Success Maternal Breastfeeding'. In order to receive the title of 'Child Friendly Hospital', the institutions are submitted to evaluation, having as criterion the global compliance of $80 \%$ of each one of the Ten Steps for the Success Maternal Breastfeeding. The accredited hospitals such as Child Friendly, once qualified, start to act as a venue of training of multi-professionals teams in the area of health, becoming recognized as centers of 'reference in maternal breastfeeding' locally or regionally. These hospitals are also characterized for guaranteeing the continuity of the lactation exclusively in the first six months inside and outside the institution, that is, they differ by offering conditions for the puerpera to have the right to breastfeed, to adequate assistance, to orientation and necessary information for the success of maternal breastfeeding.

Other aspects which influence the exclusive maternal breastfeeding are the maternal confidence in her ability to breastfeed. With this purpose there is an instrument in the literature for the evaluation of the maternal confidence during the act of breastfeeding, it is the Breastfeeding Self-Efficacy Scale (BSES). This confidence is built from four sources of information which ground the expectation of self-efficacy, as follows: personal experience (positive experiences related to previous breastfeeding), vicarious experience (observation of other mothers who also breastfed, watch videos with orientations related to breastfeed), verbal persuasion (support and encouraging of close and respected people of the women, such as aunt, mother, grandmother), emotional and physiological condition (pleasant and positive psychological and physical reactions facing breastfeeding).

The Breastfeeding Self-Efficacy Scale, in its original form has 33 items and was translated and validated in Brazil ${ }^{(8)}$. The same way, its reduced version, the Breastfeeding Self-Efficacy Scale-Short Form (BSES-SF), with 14 items, was validated in a study developed in the northeastern region of Brazil ${ }^{(9)}$.

The use of BSES-SF allows to previously know the area in which the woman has less self-efficacy in breastfeeding, allowing, when necessary, the implementation of strategies of care and promotion of maternal breastfeeding before she decides not to breastfeed or to have an early weaning. Such fact can in the medium and long term range, lead to the reduction of the rates of early weaning and, consequently to an improvement in the quality of life of the mother-child binomial $^{(8)}$.

Scientific evidences show that the exclusive maternal breastfeeding up to six months of life of the baby, is able to prevent many child diseases. For that, it is fundamental to have the mobilization of the governments and of the society for its promotion. So, the interest in revising this important subject for the world public health is justified, having the object in the present study, to determine the factors related to the length of the exclusive maternal breastfeeding and relate them with the scores of the BSES-SF. 


\section{Method}

The study had as design a descriptive and analytical cut followed by a period of 4 months.

The present research was made in a population of 300 mother-baby binomials, born in two hospitals in two cities in the southern region of Brazil, Chapecó, SC and Porto Alegre, RS.

To establish the participants of the study, the selection of the puerperas was made in a continuous, simultaneous and random manner in the two hospitals, as the deliveries occurred in the obstetric center, in the year 2012. Due to the objective of this study, there was the need of evaluation of breastfeeding in the mother-child binomial, from birth until four months of life.

The following criteria of inclusion were adopted: children with weight at birth $>2,500 \mathrm{~g}$, from normal delivery or cesarean (without intercurrences in both), from mothers with gestational age above 36 weeks, resident in urban areas. The criteria of exclusion were as follows: premature children (gestational age bellow 36 weeks); twins; low weight at birth $(<2,500 \mathrm{~g})$; children born exposed to the virus of acquired immunodeficiency; with congenital malformation; children for adoption; or resident in rural areas.

To answer the scale, at the maternity, the mothers self-applied the BSES-SF, which has 14 items and is divided into two domains: technical domain and intrapersonal thought. The technical domain consists of six questions, and the intrapersonal thought presents a combination of six questions. It presents, as options of answers, a Likert scale with five alternatives, which go from 1 , which indicates the total lack of confidence, to 5 , indicating that the mother is very $\operatorname{confident}^{(9)}$. All the items of the scale are presented in a positive manner, and the results are added in order to produce results which range from 14 to 70 . Higher results indicate high levels of self-efficacy in breastfeeding and a higher confidence of the woman in her potential to breastfeed, thus indicating, a greater probability to start and maintain the exclusive maternal breastfeed- ing for a longer period.

Besides the answers to the scale, data of the medical record were also collected: full name, age, birthdate, address and telephone; and from the pregnant women's register file: gestational age, number of pre-natal appointments, number of gestations and abortions.

After the hospital discharge, the mothers answered, on the phone, questions directed to breastfeeding, with intervals of 15 days, until the babies are 120 days old or until the interruption of the exclusive breastfeeding, in case this happens before.

Two questions were made: (1) whether they were offering natural breastfeeding exclusively and (2) whether they had started some other kind of food (for example: juice, water, tea, or any other milk formula) and whether they had offered the baby some type of food, such as salt or sweet baby food, grated fruit, soup or fruit pulp. The second question clarified the doubts regarding the first answer. In case the answer for the second question was yes, it was not considered as maternal breastfeeding, this child was left aside from the group of exclusive maternal breastfeeding and would go to the group of weaning.

The variables studied were: sex of the newborn, gestational age, non-accredited hospital as child friendly, type of delivery, maternal age, mother working outside, first pregnancy, score of the BSES-SF, maternal schooling, feeding until 120 days of life: exclusive maternal breastfeeding, maternal breastfeeding with supplement and without breastfeeding.

In order to have a descriptive analysis, the data were presented through absolute and relative frequency, description using average (standard deviation) or median (interquartile interval), according to the symmetry of the variables. The relation between the variable of denouement (type of food when the baby is 120 days old) and the potential risk factors for exclusive maternal milk of breastfeeding was evaluated through the model of logistic regression and Poisson regression, with a robust estimate of the variance, both in the bivariate analysis as well as in 
the multivariate ones. The Wald test was used to test the significance of each variable of the model. For the multivariable model, at first all the co-variables which presented values of $\mathrm{p}<0.10$ were considered. The next procedure was the exclusion, in an individual manner, of the co-variables which presented critical values of $\mathrm{p}$ (higher values and non-significant). This procedure was repeated until all the remaining variables in the model presented values of $p<0.05$. The data were analyzed in the Statistical Package for the Social Science program, version 14.0. All the tests were bidirectional and the differences were considered significant, with value of $\mathrm{p}<0.05$.

The research was approved by the Committee of Ethics in Research of the Pontíficia Universidade Católica do Rio Grande do Sul, Brazil, under no. 11/05533. All the participants received and signed a copy of the Free Informed Consent Form with information on the study and the telephone of the researcher for contact.

\section{Results}

Of the three hundred mother-child binomial, the average age of the mother was 26 years, with average gestational age of 39 weeks. Most of them (61\%) had from 7 to 13 pre-natal appointments, and 55\% of the deliveries have been normal. Concerning the maternal profile, most of the mothers worked (57\%), $87 \%$ were married, and only $34 \%$ had up to 8 years of schooling. The maternal average of score obtained in the BSES-SF was 60 points.

Of the evaluated children, the smaller proportion consisted of girls (47\%). Evaluating the exclusive maternal breastfeeding, the breastfeeding in the beginning (up to 30 days) was provided by most mothers (86\%), and this behavior kept constant with 60 days (77\%) and 90 days (69\%), whereas only 49\% of the children received exclusive breastfeeding up to 120 days of life.

Of the births occurred, $52 \%$ were in accredited hospitals as Child Friendly. Of those most participants
(51\%) were pregnant for the first time. Among the mothers with historical of other children, $96 \%$ reported experience with previous breastfeeding.

When evaluating the exclusive maternal breastfeeding at 60 days of life, the variables which were shown as risk factors for breastfeeding were: the non-accredited hospital as Child Friendly ( $\mathrm{p}=0.002)$, the schooling ( $\leq 8$ years of study) $(p=0.004)$ and the mother working $(\mathrm{p}=0.013)$. The highest punctuation in the BSES-SF ( $p=0.016)$ was a protection factor for exclusive breastfeeding. The variables age, first pregnancy, type of delivery and gestational age did not show a significant association with exclusive maternal breastfeeding at 60 days of life.

When evaluating the maternal breastfeeding at 120 days, the variables which constituted protection factors for breastfeeding were the maternal age $(p=0.039)$ and the score in the BSEF-SF $(p=0.046)$. the variables accredited hospital as child friendly, first pregnancy, type of delivery, gestational age, schooling of the mother and the mother who worked did not show significant association with exclusive maternal breastfeeding at 120 days (Table 1 ).

Table 1 - Association between exclusive maternal breastfeeding at 120 days and its potential protection factors

\begin{tabular}{|c|c|c|c|}
\hline Predictor variable & $\begin{array}{l}\text { Odds } \\
\text { ratio }\end{array}$ & IC $95 \%$ & $\begin{array}{l}\text { Value } \\
\text { of p }\end{array}$ \\
\hline $\begin{array}{l}\text { Non-accredited hospital as } \\
\text { Child Friendly }\end{array}$ & 1.193 & $0.950-1.498$ & 0.129 \\
\hline Maternal age (years) & 0.981 & 0.963-0.999 & $0.039 *$ \\
\hline First pregnancy & 0.961 & $0.765-1.206$ & 0.729 \\
\hline Type of delivery (cesarean) & 0.949 & $0.672-1.072$ & 0.168 \\
\hline Gestational age (weeks) & 0.987 & $0.912-1.077$ & 0.743 \\
\hline $\begin{array}{l}\text { Maternal Schooling (until } 8 \\
\text { years of study) }\end{array}$ & 0.917 & $0.716-1.174$ & 0.480 \\
\hline Score of BSES-SF (points) & 0.986 & $0.973-1.000$ & $0.046^{*}$ \\
\hline Mother working outside & 1.197 & 0.955-1.499 & 0.119 \\
\hline
\end{tabular}

When evaluating the score of BSES-SF as denouement, the risk factors for the score observed 
were birth in a non-accredited hospital as Child Friendly $(p<0,001)$, first pregnancy $(p=0,020)$, type of delivery $(p=0,003)$ and maternal schooling until 8 years of study $(\mathrm{p}=0,001)$ (Table 2 ).

Table 2 - Association between the score of BSES-SF and their potential risk factors

\begin{tabular}{|c|c|c|c|}
\hline Predictor variable & $\begin{array}{l}\text { Odds } \\
\text { ratio }\end{array}$ & IC $95 \%$ & $\begin{array}{c}\text { Value } \\
\text { of } p\end{array}$ \\
\hline $\begin{array}{l}\text { Non-accredited hospital as } \\
\text { Child Friendly }\end{array}$ & 1.061 & $1.034-1.088$ & $<0.001^{*}$ \\
\hline Maternal age (years) & 1.001 & $0.999-1.003$ & 0.228 \\
\hline First pregnancy & 1.032 & $1.005-1.059$ & $0.020^{*}$ \\
\hline Type of delivery (cesarean) & 0.96 & $0.935-0.986$ & $0.003^{*}$ \\
\hline Gestational age (weeks) & 1.006 & $0.998-1.014$ & 0.150 \\
\hline $\begin{array}{l}\text { Maternal Schooling (until } 8 \\
\text { years of study) }\end{array}$ & 1.043 & $1.016-1.07$ & $0.001^{*}$ \\
\hline Mother working outside & 1.016 & $0.99-1.044$ & 0.229 \\
\hline
\end{tabular}

The social demographic and obstetric variables which were significant for the type of hospital were: the score of BSES-SF (0.000) and the three groups of breastfeeding (0.002) (Table 3).

Table 3 - social demographic and obstetric variables according to the type of accrediting as Child Friendly Hospital Institution

\begin{tabular}{|c|c|c|c|}
\hline Variables & $\begin{array}{l}\text { Accredited } \\
\mathbf{n}(\%)\end{array}$ & $\begin{array}{c}\text { Non-accredited } \\
\mathbf{n}(\%)\end{array}$ & $\mathbf{p}$ \\
\hline Sex of the newborn (male) & $86(56.0)$ & $72(50.0)$ & 0.355 \\
\hline $\begin{array}{l}\text { Gestational age (weeks), } \\
\text { average } \pm \text { standard deviation }\end{array}$ & $39 \pm 1$ & $38 \pm 1$ & 0.121 \\
\hline Type of delivery (normal) & $83(54.0)$ & $81(56.0)$ & 0.728 \\
\hline $\begin{array}{l}\text { Age of the mother, average } \pm \\
\text { standard deviation }\end{array}$ & $25 \pm 6$ & $26 \pm 6$ & 0.232 \\
\hline Mother working outside (yes) & $78(50.0)$ & $57(39.0)$ & 0.063 \\
\hline First pregnancy (yes) & $84(54.0)$ & $70(48.0)$ & 0.355 \\
\hline $\begin{array}{l}\text { Score of BSES-SF, average } \pm \\
\text { standard deviation }\end{array}$ & $58 \pm 8$ & $62 \pm 5$ & $0.000^{*}$ \\
\hline Breastfeeding at 120 days & & & $0.002^{*}$ \\
\hline $\begin{array}{l}\text { Exclusive maternal } \\
\text { breastfeeding }\end{array}$ & $82(54.0)$ & $64(45.0)$ & \\
\hline $\begin{array}{l}\text { Breastfeeding + supplement } \\
\text { or food }\end{array}$ & $60(40.0)$ & $49(36.0)$ & \\
\hline Without breastfeeding & $10(7.0)$ & $29(20.0)$ & \\
\hline
\end{tabular}

\section{Discussion}

In this work, in a period of 120 days, the maternal age showed to be a protection for maternal breastfeeding, but such variable did not prevailed at 60 days. The women with age $>20$ years breastfed for a longer period, possibly for having more knowledge and more experience concerning maternal breastfeeding. Studies ${ }^{(6,10-12)}$ showed that the maternal age below 20 years, interferers negatively in breastfeeding. However, other studies show controversy on the maternal age as a casual factor of the early weaning ${ }^{(2-3)}$. The educational instruction can be a factor of confusion in the relation between the maternal age and educational level. In the present study, both predictor variables presented significant relation with exclusive breastfeeding at 60 days.

In our findings, schooling (until 8 years of studying) showed to be a risk factor for breastfeeding at 60 days and for the score of the BSES-FS, but it did not show any significant association at 120 days. Probably the women without education or with little education do not know the importance of the exclusive maternal breastfeeding until at least 6 months of life, once they don't know the high nutritious and caloric value of the maternal milk to the newborn, neither concerning the necessary nutrients to his growth and development. Most of the works showed that the maternal breastfeeding is effective in women with higher schooling ${ }^{(2-6)}$. However, other reports ${ }^{(6,10-16)}$ showed a higher prevalence of interruption of the exclusive maternal breastfeeding among the women of higher schooling. A possible explanation for this finding is that the higher level of schooling increases the chances of the mothers to have a steady job and the return to work in the first month of life of the child can jeopardize the process of breastfeeding.

The cesarean delivery showed to be a protection factor for the score of the BSES-SF. The cesarean can interfere in the beginning of breastfeeding, concerning the willing of the mother to cope with pain and discomfort of the surgery, besides making the 
positioning of the baby difficult, due to the mandatory rest of the mother in bed. However, there are controversies concerning the relation between the early weaning and the type of delivery ${ }^{(2-3)}$, whereas, other works do not present significant results between the type of delivery and weaning ${ }^{(13-14)}$.

Working outside showed to be associated to maternal breastfeeding at 60 days, but without significant association with breastfeeding at 120 days; however, it showed to be a risk factor for the scores of the BSES-SF.

Similar results in the present study in other work $^{(15)}$ did not show statistically significant difference between exclusive breastfeeding and parity, however the first pregnancy showed to be a risk factor for the score of the BSES-SF. Probably for being the first child there is the inexperience in breastfeeding, the fear and the insecurity of doing something wrong and not managing to feed the child, indicating as a risk factor for the self-efficacy in breastfeeding. Being aware of this matter, the Health Department warns for the risk of early weaning among the primparous women and emphasizes the necessary attention to the women in their first pregnancy.

Being born in an accredited hospital as the Child Friendly Hospital Institution showed to be a protection factor for exclusive maternal breastfeeding at 60 days. Although the child was born in a hospital which supports breastfeeding in several stages, from the arrival until the discharge of the mother with her child, this fact did not collaborate with the permanence of breastfeeding at 120 days of life. A research ${ }^{(7)}$ showed that the babies of mothers who came from a Child Friendly Hospital Institution were breastfed for a longer period when compared to the ones who were born in the other hospital institutions. Despite the effort of the health services and of the accredited institutes such as the Child Friendly Hospital Institution, the prevalence of maternal breastfeeding is low, and it is necessary to have a revision of the practices adopted, especially during the pre-natal and mediate postpartum period, in order to make the women be- come more self-confident and consequently prolong maternal breastfeeding for a longer period.

The results of this work showed that the score of the BSES-SF and the age were protection factors of maternal breastfeeding at 4 months. The non-accredited hospital as Child Friendly Hospital Institution, the maternal schooling and the type of delivery consisted risk factors for the score of BSES-SF. The mothers, independently of their social position, were confident concerning their condition of nursing mother, a positive aspect for the maintenance of maternal breastfeeding ${ }^{(17)}$.

In the results of this study, the score of the BSES-SF showed to be a risk factor for the breastfeeding at 60 and at 120 days of life of the baby. A research showed that $27 \%$ of the women with low levels of confidence in breastfeeding, during the pre-natal period, interrupted the maternal breastfeeding within the first week of postpartum ${ }^{(8)}$. Also, women with low level of confidence in breastfeeding had a higher risk of interrupting breastfeeding than those who had total confidence ${ }^{(18)}$. Self-efficacy was a complement of motivation, once it is related to the acting and the persistence, and plays an important role in the acquisition of the behavior and its change.

In the present work, the risk factors associated to exclusive maternal breastfeeding at 60 days were: non-accredit hospital as Child Friendly Hospital Institution, schooling (until 8 years of studying) and the mother working outside. The highest score in the test of BSES-SF was a protection factor for exclusive breastfeeding ${ }^{(9)}$. At 120 days, the variables which showed to be protection factors for exclusive breastfeeding were the maternal majority age and the score in the test of BSES-SF.

It is worth highlighting that studies of cut can be subject to limitations imposed by biases. However, the limitations that could be registered in this work were minimal, once there were no losses of assistance.

Another highlight was the fact that the information on the denouement, that is, on the modification on the eating plan of the child along the time can have 
been, at some time, distorted by the child's caregivers and the classification in categories in exposition were also altered. This fact can occur even if clear rules have been defined for the classification of the exposition and of the denouement. It should be highlighted that if this occurred in this study, it must have reached indistinctly the groups of exposition, diluting the influence of the error of the classification in the measure of the denouement.

\section{Conclusion}

The study revealed that the risk factors to jeopardize self-efficacy in maternal breastfeeding were: schooling (women with up to 8 years of studying), the first pregnancy women and the birth in a non-accredited institution as Child Friendly Hospital Institution.

The protection factors for maternal breastfeeding at 60 days were: the mothers schooling above 8 years, the high score of the Breastfeeding Self-Efficacy Scale-SF the accredited hospital as Child Friendly and the mother working outside. However, the protection factors to the exclusive maternal breastfeeding at 120 days of the baby were different: only the age of the mother and the high score of Breastfeeding Self-Efficacy Scale.

When evaluating the relation of the test of Breastfeeding Self-Efficacy Scale as denouement, it is concluded that the risk factors for the low score observed were: the birth in the non-accredited hospital as Child Friendly, the first pregnancy, the type of delivery (cesarean) and the maternal schooling are until 8 years of studying.

The conclusions of the present research can contribute for the reflection of other similar realities, once the methodology common to other studies was used here. Such reflections can show ways to overcome the difficulties faced by the professionals of the services of health in the support to the woman who breastfeeds and to her family.

\section{Acknowledgments}

I would like to thank for the collaboration of the nursing team of both hospitals where the data were collected, to Carla Hotmann, secretary of the post-gradutation program of PUC-RS and to Doctor Professor Rita Matiello, who evaluated the data.

\section{Collaborations}

Margotti E contributed for the conception, interpretation of the data and writing of the article. Epifanio $M$ contributed for the orientation of the work.

\section{References}

1. World Health Organization (WHO). Global strategy on infant and young child feeding [Internet]. Geneva: WHO; 2003 [cited 2014 Sept 4]. Available from:http://www.who.int/nutrition/topics/ global_strategy/en/

2. Souza SNDH, Migoto MT, Rossetto EG, Mello DF. Prevalence of breastfeeding and associated factors in the municipality of Londrina (PR, Brazil). Acta Paul Enferm. 2012; 25(1):29-35.

3. Salustiano LPQ, Diniz ALD, Abdallah VOS, Pinto RMC. Factors associated with duration of breastfeeding in children under six months. Rev Bras Ginecol Obstet. 2012; 34(1):28-33.

4. Bezerra VLVA, Nisiyama AL, Jorge AL, Cardoso RM, Silva EF, Tristão RM. Aleitamento materno exclusivo e fatores associados a sua interrupção precoce: estudo comparativo entre 1999 e 2008. Rev Paul Pediatr. 2012; 30(2):173-9.

5. Boccolini CS, Carvalho ML, Oliveira MIC, Vasconcellos AGG. Fatores associados à amamentação na primeira hora de vida. Rev Saúde Publica. 2011; 45(1):69-78.

6. Carrascoza KC, Possobon RF, Ambrosano GMV, Costa Junior AL, Moraes ABA. Determinants of the exclusive breastfeeding abandonment in children assisted by interdisciplinary program on breast feeding promotion. Ciênc Saúde Coletiva. 2011; 16(10):4139-46. 
7. Sampaio PF, Moraes CL, Reichenaheim ME, Oliveira ASD, Lobato G. Hospital Amigo da Criança: fator de proteção ao aleitamento materno? Cad Saúde Pública. 2011; 27(7):1349-61.

8. Oriá MOB, Ximenes LB. Translation and cultural adaptation of the breastfeeding self-efficacy scale to portuguese. Acta Paul Enferm. 2010; 23(2):2308.

9. Dodt RCM, Ximenes LB, Almeida PC, Oriá MOB, Dennis CL. Psychometric assessment of the short form version of the breastfeeding self-efficacy scale in a brazilian sample. J Nurs Educ Pract. 2012; 3(2):66-73.

10. Vitor RS, Vitor MCS, Oliveira TM, Corrêa CA, Menezes HS.Aleitamento materno exclusivo: análise desta na região sul do Brasil. Rev AMRIGS. 2010; 54(1):44-8.

11. Ramos CV, Almeida JAG, Saldiva SRDM, Pereira LMR, Alberto NSML, Teles JBM, et al. Aleitamento materno nos hospitais em Teresina-PI, 2006. Epidemiol Serv Saúde. 2010; 19(2):115-24.

12. Araújo NL, Lima LHO, Oliveira EAR, Carvalho ES, Duailibe FT, Formiga LMF. Infant feeding and factors related to breastfeeding. Rev Rene. 2013; 14(6):1064-72.
13. Arantes CIS, Oliveira MM, Vieira TCR, Beijo LA, Gradim CVC, Goiatá SLT. Breastfeeding and feeding practices for infants under six months of age from Alfenas, Minas Gerais, Brazil. Rev Nutr. 2011; 24(3):421-9.

14. Caetano MC, Ortiz TTO, Silva SGL, Souza ISS, Sarni ROS. Alimentação complementar: práticas inadequadas em lactentes. J Pediatr. 2010; 86(3):196-201.

15. Brecailo MK, Corso ACT, Almeida CCB, Schmitiz BAS. Aleitamento materno exclusivo. Rev Nutr. 2010; 23(4):553-63.

16. Leone CR, Sadeck LSR. Fatores de risco associados ao desmame em crianças até seis meses de idade no município de São Paulo. Rev Paul Pediatr. 2012;30(1):21-6.

17. Dodt RCM, Ferreira AMV, Nascimento LA, Macêdo AC, Joventino ES, Ximenes LB. Influence of health education strategy mediated by a self-efficacy breastfeeding serial album. Texto Contexto Enferm. 2013; 22(3):610-8.

18. Awano M, Shimada K. Development and evaluation of a self care program on breastfeeding in Japan: A quasi-experimental study. Int Breastfeed J [Internet]. 2010[cited 2014 Sept 4]; 5(9)1-10. Available from: http://www.internationalbreastfeedingjournal.com/content/5/1/9 